\title{
NELL1 Gene
}

National Cancer Institute

\section{Source}

National Cancer Institute. NELL1 Gene. NCI Thesaurus. Code C128934.

This gene is involved in the positive regulation of osteoblast differentiation. 